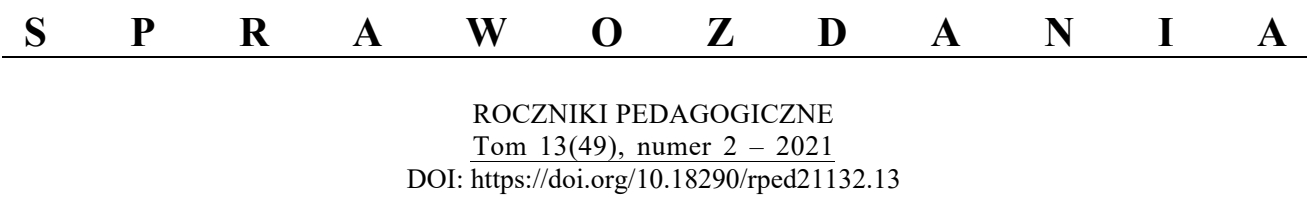

MAŁGORZATA ŁOBACZ

Instytut Pedagogiki KUL

e-mail: malgorzata.lobacz@kul.pl

ORCID: https://orcid.org/0000-0002-1476-8278

\title{
SPRAWOZDANIE Z KONFERENCJI „OSOBA PUNKTEM WYJŚCIA I DOJŚCIA W EDUKACJI SZKOLNEJ"
}

Lublin, 24 listopada 2020 roku

Konferencja „Osoba punktem wyjścia i dojścia w edukacji szkolnej”, która odbyła się 24 listopada 2020 roku w Katolickim Uniwersytecie Lubelskim Jana Pawła II, została zorganizowana przez Katedrę Dydaktyki, Edukacji Szkolnej i Pedeutologii Instytutu Pedagogiki KUL, pod kierownictwem prof. dr hab. Krystyny Chałas, we współpracy z Wydawnictwem KUL, Narodowym Instytutem Wolności - Centrum Rozwoju Społeczeństwa Obywatelskiego, a także Kuratorium Oświaty w Lublinie. Wydarzenie to było połączone z promocją książki autorstwa Krystyny Chałas i Małgorzaty Łobacz, zatytułowanej Przymioty osoby ludzkiej - edukacja aksjologiczna $i$ wychowanie ku wartościom (Lublin: Wydawnictwo KUL 2020).

Konferencja odbyła się zarówno w formie stacjonarnej, jak i była możliwość udziału zdalnego - za pośrednictwem transmisji internetowej, realizowanej przez Uniwersyteckie Centrum Medialne KUL.

Konferencję otworzyła prof. dr hab. Krystyna Chałas, kierownik Katedry Dydaktyki, Edukacji Szkolnej i Pedeutologii KUL, która przywitała zgromadzonych w sali konferencyjnej oraz łączących się zdalnie gości: Ministra Edukacji i Nauki - Przemysława Czarnka, Prorektora KUL - ks. prof. dr hab. Mirosława Sitarza oraz Lubelskiego Wicekuratora Oświaty - Eugeniusza Pelaka, a także 
przybyłych dyrektorów szkół i nauczycieli. Profesor Chałas wyraziła swoją wdzięczność Narodowemu Instytutowi Wolności za pomoc w wydaniu promowanej książki.

Słowo wstępne wygłosił Prorektor ds. Misji i Administracji - ks. prof. dr hab. Mirosław Sitarz. W swojej wypowiedzi zwrócił uwagę na wartość osoby. Nawiązując do książki Przymioty osoby ludzkiej - edukacja aksjologiczna $i$ wychowanie ku wartościom, Ksiądz Profesor zwrócił uwagę na problem odchodzenia od wartości, a co za tym idzie - konieczność przywrócenia rangi wychowania ku wartościom wśród nauczycieli, uczniów i rodziców.

Następnie głos zabrał Minister Edukacji i Nauki - prof. dr hab. Przemysław Czarnek, który wskazał na istotną rolę prawdy i miłości do dobra wśród nauczycieli i wychowawców. Zdaniem Ministra nauczyciel będzie wychowywał do autentycznej dojrzałości osoby wówczas, gdy działalność edukacyjną i wychowawczą będzie przenikać wizja człowieka jako bytu osobowego.

Wystąpienia wprowadzające w konferencję zwieńczyła wypowiedź Eugeniusza Pelaka - Lubelskiego Wicekuratora Oświaty, który wyraził swoją wdzięczność organizatorom konferencji, na czele z prof. Krystyną Chałas. $\mathrm{W}$ dalszych słowach odniósł się do roli wartości w procesie wychowania.

Część zasadniczą konferencji poprowadziła prof. Krystyna Chałas. Pierwszy referat, zatytułowany Fenomen osoby $i$ jej przymioty, wygłosiła dr hab. Lucyna Dziaczkowska, prof. KUL. W swoim wystąpieniu prelegentka zwróciła uwagę na cztery obszary w ramach omawianego zagadnienia: osoba jako fenomen wychowania i kategoria pedagogiczna, propozycje ujęcia przymiotów osoby ludzkiej, czyn jako najpełniejszy sposób wyrażenia osoby, pytania o możliwości wspomagania osobowych relacji w rzeczywistości szkolnej. Analizując pierwszy obszar, odniosła się do myśli Karola Wojtyły. Podkreśliła również znaczenie integralności ludzkiej osoby, powołując się na teorię wychowania Stefana Kunowskiego. W dalszej części referatu zaprezentowała propozycje ujmowania przymiotów osoby ludzkiej. Ważną częścią wypowiedzi był problem dynamizmu osoby ludzkiej, jej czynów oraz podstawowe pytania dotyczące wspomagania osobowych relacji w szkole. Profesor podjęła zagadnienie związane ze wspomaganiem rozwoju osobowego uczniów, nauczycieli i rodziców, a także odnoszące się do osobowych relacji zachodzących między tymi podmiotami.

Następnie głos zabrała prof. dr hab. Krystyna Chałas, która wygłosiła referat na temat: Godność pierwszym celem wychowawczym i czynnikiem integrujacym rozumność - madrość, wolność, odpowiedzialność. Zaprezentowała w nim zakresy definicyjne pojęcia „godność”, charakterystykę godności 
osobowej i osobowościowej, a następnie związki i zależności oraz cele dydaktyczne, które wynikają między tymi rodzajami godności. Zaakcentowała w swojej wypowiedzi, że podstawą godności jest istota człowieka, kim jest on sam w sobie. Osoba ludzka jest zawsze celem, nigdy środkiem do celu. Profesor Chałas wskazała także na problem nadużywania i nierozumienia pojęcia godności oraz omówiła istotne różnice zachodzące między pojęciem godności osobowej i godności osobowościowej. Zwróciła również uwagę, że człowiek doskonali siebie poprzez stawiane cele, sposoby realizacji, wartościowanie siebie i efektów na bazie swojej podstawy aksjologicznej. Ważne jest tu urzeczywistnianie własnej, ale właściwej hierarchii wartości - prowadzącej do pełni człowieczeństwa. Na zakończenie prelegentka zaprezentowała cele wychowania, które implikuje godność osobowa.

W dalszej części konferencji referat pt. Odpowiedzialność trajektoria $w$ świat dobra zaprezentowała dr hab. Alina Rynio. Swoją wypowiedź rozpoczęła, odwołując się do trzech zasadniczych pytań: Czym jest odpowiedzialność i kiedy staje się trajektorią? Jakie warunki są potrzebne, aby taka odpowiedzialność zaistniała? Jak jest rozumiane samo dobro i co kryje się w pojęciu szeroko rozumianego świata dobra? Zwróciła uwagę na istotę, treść i zakres pojęcia odpowiedzialności. Zaznaczyła, że sens pojęcia odpowiedzialność zmienia się wraz z kontekstem i sytuacją, intencją rozmówcy. Podkreśliła też, że pojęcie to najczęściej rozumiane jest jako postawa wynikająca ze świadomości i wolności; dotyczy ono słów, myśli, czynów, a także zaniedbań. Omówiła również rolę odpowiedzialności w procesie wychowania człowieka. W dalszej części referatu prof. Rynio zaprezentowała rozumienie pojęcia dobra $\mathrm{z}$ perspektywy interdyscyplinarnej. W podsumowaniu podkreśliła, że odpowiedzialne wychowanie w warunkach ponowoczesności stawia wymóg realizmu wychowawczego pozwalającego na rozpoznawanie zagrożeń i odważne podejmowanie prawidłowych decyzji wychowawczych oraz konieczność integralnego wychowania człowieka.

Kolejny referat, zatytułowany Twórczość jako zadanie, wygłosiła dr Anna Badora, która w pierwszej kolejności omówiła pojęcie twórczości. Następnie zaprezentowała główne aspekty twórczości: procesualny (dotyczący działalności teoretycznej i praktycznej), personologiczny (celem jest tu twórczy człowiek wraz ze swoimi zdolnościami), atrybutywny (akcentujący oryginalność wytworu) oraz aspekt stymulatorów i inhibitorów (związany m.in. z cechami osobowościowymi). W dalszej części prezentacji omówiła przykłady twórczości, rodzaje twórczości oraz problem twórczości jako warunku roz- 
woju cywilizacji. Na zakończenie przedstawiła zagadnienie wychowania jako szczególnego rodzaju twórczość.

W dalszej części konferencji głos zabrał ks. dr hab. Adam Maj, prof. KUL, prezentując referat pt. Miłość i odpowiedzialność - wzajemne związi i zależności. Wystąpienie Księdza Profesora było oparte na trzech zasadniczych blokach tematycznych. W ramach pierwszego z nich, zatytułowanego „Osobowa podstawa miłości i odpowiedzialności”, prelegent przedstawił pojęcie miłości, istotę i uniwersalne cechy miłości, osobowy związek miłości i odpowiedzialności. W ramach drugiego bloku tematycznego, „Miłość i odpowiedzialność - dynamika związków i zależności”, podjęte zostały następujące kwestie: przedmiotowy zakres miłości i odpowiedzialności, ontyczny związek miłości i odpowiedzialności, dobro a miłość i odpowiedzialność, dialogiczny wymiar miłości i odpowiedzialności, rozwój i stopniowalność miłości i odpowiedzialności, powinnościowy charakter miłości i odpowiedzialności. W ramach trzeciego bloku tematycznego, „Miłość i odpowiedzialność w wychowaniu", ks. prof. Maj przybliżył problem miłości i odpowiedzialności wychowawczej. Na zakończenie swojego wystąpienia podkreślił, że miłość i odpowiedzialność wymagają wychowania, czyli wspomagania poprzez posługę odpowiedzialnego wychowawcy.

Wystąpienia wykładowców zwieńczyła dyskusja z udziałem uczestników zarówno w sali konferencyjnej, jak i łączących się zdalnie. W ramach dyskusji wielokrotnie zwrócono uwagę na rangę podjętego tematu, na problem osoby ludzkiej i jej przymioty. Poruszony został problem relatywizmu aksjologicznego, trudności związanych z wyborem wartości przez młodych ludzi. Wskazano też na odpowiedzialność za wychowanie, która spoczywa na rodzicach i wychowawcach.

Konferencję zamknęła prof. Krystyna Chałas, która wyraziła swoją wdzięczność współorganizatorom za zorganizowanie konferencji, prelegentom za przygotowanie swoich wystąpień $\mathrm{i}$ wszystkim uczestnikom za udział $\mathrm{w}$ tym wydarzeniu. 